\title{
Innovative Technology in the Pacific: Building Resilience for Vulnerable Communities
}

\author{
Jeremy M. Hills ${ }^{\text {ab }}$, Evanthie Michalena ${ }^{b^{*}}$ and Konstantinos J. Chalvatzis ${ }^{\text {cd }}$
}

${ }^{a}$ Institute of Marine Resources, Faculty of Science, Technology \& Environment, Private Bag, Laucala Campus, Suva, Fiji. Tel: (+679) 323 2995, e-mail: jeremy.hills@usp.ac.fj

${ }^{\mathrm{b}}$ Sustainability Research Centre, University of the Sunshine Coast, Maroochydore DC Qld 4558 Australia.

${ }^{c}$ Norwich Business School, University of East Anglia, NR4 7TJ, Norwich, UK. Tel: +44 160359 7241, email: k.chalvatzis@uea.ac.uk

${ }^{\mathrm{d}}$ Tyndall Centre for Climate Change Research, University of East Anglia, NR4 7TJ, Norwich, UK.

\begin{abstract}
Transitioning to sustainability will require innovation, not just in technological and economic terms but also in governance and culture. The work presented here sought a remote, vulnerable island context (Fiji, South Pacific) to enable further insight into the innovation process related to resilience and sustainability. The innovation targeted by this work was off-grid solar renewable energy (RE) systems framed as a development instrument to promote local, community-based resilience to climate change through increased livelihood security and reduction of climate change effects. Applying a local-level resilience framework to solar technology use, we conclude that the RE system can improve resilience, however, unintended consequences included a rush for energy usage causing a "tragedy of commons" of finite stored energy and subsequently increased supplementary fossil fuel use. This suggests that there are still missed resilience opportunities in the way that the innovation is implemented in developing countries and remote areas in particular. Further analysis demonstrated that improved planning at the socio-technological interface has the potential to strengthen communities' resilience. With significant RE investments required for a transition to a low-carbon future in many developing countries, there is a pressing need to effectively introduce innovative uses of technologies. Existential threats to many local communities, and some nations in the Pacific may mean that sub-optimal innovation will not be enough.
\end{abstract}

\section{Key-words:}

Innovation; Pacific Island Countries; Renewable Energy; Vulnerable Communities; Resilience

\section{Highlights:}

- The research provides an insight into the innovation used as a tool for climate change adaptation and resilience

- Resilience coming from off-grid renewable energy was determined in rural vulnerable villages in Fiji.

- There were missed resilience opportunities due to the design of the innovation implementation process.

- Resilience benefits of renewable energy need improved planning at the socio-technological interface.

\section{List of Abbreviations}

$\mathrm{CO}_{2}$

Carbon Dioxide

GHG

Greenhouse Gas Emissions

INDCS

Intended Nationally Determined Contributions

IPCC

Intergovernmental Panel on Climate Change 


$\begin{array}{ll}\text { LED } & \text { Light-Emitting Diode } \\ \text { MMM } & \text { Management-Maintenance-Monitoring } \\ \text { NGO } & \text { Non-Governmental Organizations } \\ \text { OGSS } & \text { Off-Grid Solar Systems } \\ \text { PSIDS } & \text { Pacific Small Island Developing States } \\ \text { PV } & \text { Photovoltaic } \\ \text { SDG } & \text { Sustainable Development Goals } \\ \text { UN } & \text { United Nations } \\ \text { UNFCCC } & \text { United Nations Framework Convention on Climate Change } \\ \text { USD } & \text { United States Dollars }\end{array}$

\section{Introduction}

\subsection{Background}

Sustainability is being increasingly seen as requiring a transformation or a transition, rather than being the inevitable consequence of contemporary development trajectories (Olsson, Galaz, \& Boonstra, 2014). Successful achievement of ambitious Sustainable Development Goals (SDG) of the UN 2030 Agenda for Sustainable Development will require major transitions, not only in policies and technologies, but in modes of innovation. An expanding band of resilience scholars since the mid-1990s has been studying transitions toward improved ecosystem stewardship and sustainability (e.g. (Olsson, Folke, \& Hahn, 2004) (Chapin, et al., 2010) (Folke, Carpenter, Walker, Scheffer, Chapin, \& Rockstrom, 2010). Integrating transition management and resilience theory can contribute to the understanding of how to form niches for experimenting with initiatives that increase human well-being in the face of uncertainty and change, while simultaneously supporting ecosystem capacity (Olsson et al., 2014). This key research focus areas invokes innovation and the dynamics of interactive innovation within which peoples, researchers, businesses and policy makers, and others can coproduce resilience and sustainability.

Innovation is framed not just in technological and economic terms but also in governance and culture. Island communities lend themselves to understanding such processes of innovation as they encapsulate many of the sustainable development challenges (Kelman, Burns, \& Machado des Johnasson, 2015) (Connell, 2013) but are relatively small scale and unbuffered against shocks such as oil price spikes and natural extreme events. This small scale of island communities can make it easier to encompass diverse disciplines and information data within the same study (Mercer, Kelman, Taranis, \& Suchet-Pearson, 2010)(Mercer et al., 2010). This multidisciplinary understanding is required for effective local responses to sustainability challenges, which is why island case studies have had such a large impact on participatory processes for sustainable development (Kelman, Lewis, Gaillard, \& Mercer, 2011). There is resonance to the statement that "Vulnerability is the birthplace of innovation, creativity and change" (Brown B. , 2012) as measured by the interest of around 3.2 million people from around the planet (Walters, 2012). This work presented here sought a remote, vulnerable island context to enable further insight into the process of innovation implementation for resilience and sustainability.

\subsection{Vulnerability, resilience and adaptation concepts in Pacific islands}

Within the largest ocean of the world are located some of the smallest island countries. Pacific Small Island Developing States (PSIDS) are mostly remote and highly dispersed. Kiribati, for instance, has 112,000 inhabitants on 33 coral atolls which are spread over 3.5 million $\mathrm{km}^{2}$ of ocean, an area larger than the land area of India. Most PSIDS have independent political systems with full jurisdictional autonomy and their own identity (Connor, 2008); they thus possess considerable self-determination of their development trajectory. However, this remoteness and selfgovernance is offset by economic reliance on other countries such as development assistance (World Bank, 2015)(OECD, 2016). This high degree of international commitment in narrowly-based economics make those nations particularly attractive when it comes to promulgating innovation. 
The Intergovernmental Panel on Climate Change (IPCC) defines vulnerability as the degree to which a system is susceptible to and unable to address climate variability and climate adverse impacts (IPCC, 2014). Vulnerability can also be conceptualised as "a combination of the geographical and temporal proximity to a hazard (exposure) and the propensity for exposure to result in harm (sensitivity)" (Jacobs, Lee , O'Toole, \& Vines, 2014). Between 2001 and 2010, natural disasters have, on average, affected 232 million people and caused more than US\$100 billion in damage worldwide each year (Guha-Sapir, Vos, Below, \& Ponserre, 2011). In 2011, four PSIDS were in the top 15 World Risk positions (in terms of exposure, susceptibility, coping capacities and adaptive capacities) (United Nations, 2011). PSIDS are particularly sensitive to adverse impacts of climate change (United Nations, 2011) (United Nations , 2011b) (United Nations, 2015) leading to a capital stock loss 20 times greater each year compared to Europe and Central Asia (United Nations, 2015). Populations who live below the poverty line may be especially vulnerable to disasters (Maru, Stafford Smith, Sparrow, Pinho, \& Dube, 2014); Fiji for example has $>30 \%$ of the population living below the poverty line (Asian Development Bank, 2014).

Various forms of adaptation can be used to alleviate climate change vulnerabilities (Pelling, 2011). Adaptation refers to the decision-making process and the set of actions undertaken from individuals, communities, organizations and governments to deal with current or future predicted change (Engle, 2011) (McLennan \& Handmer, 2012) (Fidelman, Leitch, \& Nelson, 2013) (Keys, Bussey, Thomsen, Lynam, \& Smith, 2014). Increasingly authors argue that adaptive capacity is a function of household-level adaptive decision-making and action (Moser \& Pike, 2015) (Collins, 2015) (Elrick-Barr, Smith, Preston, Thomsen, \& Baum, 2016). However, adaptation cannot suppress all climaterelated impacts (Warner \& Van der Geest, 2013) (Warner, K.; Van der Geest, K.; Kreft, S., 2013) (Mathew \& Akter, 2015) particularly in small island states (Alliance of Small Island States, 2008) (Monnereau \& Abraham, 2013).

Most definitions of "resilience" include two key-elements: a) resilience concerns systems, countries, communities or households, b) resilience concerns the ability to manage exposure to hazards, shocks or stresses through maintaining or transforming living standards aiming at long-term prospects (Christopher \& Rutherford, 2004) (UNISDR, 2005) (Cutter, et al., 2008), (UkAid, 2011) (Akter \& Mallick, 2013). Resilience is, therefore, a dynamic process and is characterised by multiple adaptive cycles interacting across a range of scales and dimensions (Brown \& Westaway, 2011)(Craeynest, 2010) (Manyena, 2006). Fostering resilience, however, is difficult as is measuring resilience (CARI, 2017). This is probably the reason why there are projects aimed at improving the livelihood of vulnerable communities but which miss the chance to reach optimal resilience gains.

\subsection{Resilience and energy innovation in the Pacific islands}

Innovation is generally considered to be the result of a process that brings together novel ideas / technologies in a way that they affect society and meet growing consumer demand (OECD , 2005) (EPSC, 2017) (OECD, 2010). The ability to innovate is also location specific (Tim, 2002). The miniscule land area of PSIDS within a vast ocean (1.8\% land and $98.2 \%$ water (Fifita, 2012)) and limited domestic fossil fuel resources result in a heavy reliance on imported fossil fuels (Singh, 2012) and challenges related to energy security (Dornan,M., 2014) (Michalena \& Hills, 2016). Long diesel supply routes lead to oil cost escalation (Prasad, Schulte, \& Bijay, 2013) and the limited population spread across thousands of islands challenges fuel delivery. More than $95 \%$ of fossil fuel is imported into the Pacific (Woodruff, 2007a) and the energy demand keeps increasing (Bayar \& Alp Ozel, 2014). It is estimated that 70\% of Pacific households do not have access to electricity and the majority of those households are located in rural areas (Dornan,M., 2014).

Innovation in energy systems is a viable option to address energy resilience and security in countries with growing electricity demand, challenging economic circumstances and environmental targets (Michalena \& Frantzeskaki, 2013) (Chalvatzis \& Rubel, 2015). All PSIDS are progressing with the roll-out of renewable energy (IRENA, 2016). Although PSIDS do not emit large quantities of $\mathrm{CO}_{2}$ themselves (EU, JRC, 2011), the Pacific region is an assistance priority for development partners (Nutall, Newell, Prasad, Joeli, \& Holland, 2014) (New Zealand Government, 2016). The focus on mitigation, through increased renewable energy feeding to grids, is apparent in the INDCs (Intended 
Nationally Determined Contributions) submitted by PSIDS to UNFCCC (Republic of Fiji, 2015). However, this focus misses some of the most vulnerable parts of PSIDS societies, the off-grid rural poor communities that produce negligible GHG emissions per capita but bear the brunt of climate change impacts. For those communities RE has no mitigation function as in their case they are trying to initiate electricity supply rather to switch to a lower carbon supply option.

Innovation in energy systems, both technological and integrative is fundamental in solidifying the benefits of renewable energy either in terms of controlling emissions (Zafirakis, Chalvatzis, \& Baiocchi, 2015) or facilitating the energy supply chain in a wider interconnected system (Zafirakis, Chalvatzis, Baiocchi, \& Daskalakis, 2016). The innovative use of energy technologies can also create resilience for individuals, households and communities against the effects of climate change. The literature which tackles renewable energy's potential capacity to address adaptation and building resilience to climate variability at a local/community level, is limited (Stone, 2013) (Perera, Boyd, Wilkins, \& Itty, 2015). A systematic review (Perera, Boyd, Wilkins, \& Itty, 2015) notes that "only a few" documents contained "evidence demonstrating the link all the way through from access to energy to adaptation and building resilience to climate change and climate variability"; this finding was significant in framing the energy innovation process as the object of study.

\subsection{Scope and aims}

Our research lens focuses on small, remote and traditional Fijian communities with customary tenure of natural resources. These communities are located in inherently vulnerable coastal locations with implemented householdand community-innovation in the renewable energy sector. Within this focus, we exclusively target innovationcreated, place-based resilience accrued at the household- or village-level and accessible to the vulnerable and poor members of these communities. There is a research need to better map the level of existing indigenous innovation capabilities across a range of different technological areas in poorer countries, in order to extend understanding of the role of innovation in alternative development pathways compared to those underpinned by existing energy socio-technical regimes (Geels, 2004) (Geels \& Kemp, 2007) (Bryne, Smith, Watson, \& Ockwell, 2011). In addition, Olsson et al. (2014) noted the need for future resilience research in innovation and the social, technological and ecological interactions in relation to sustainability.

Although resilience can be a difficult concept to operationalise (Klein, Nicholls, \& Thomalla, 2003) (Darnhofer, I., 2014) the work presented here uses case studies to provide an understanding of how innovation builds resilience within communities (Gawith, Deigneault, \& Brown, 2016). The innovation targeted by this work was off-grid solar systems which were new to the selected communities and new to the selected island and sparse nationally (Fiji) and regionally (Pacific). Those innovative solar systems are herein framed as a development instrument to promote local, community-based resilience to climate change through increased livelihood security and reduction of climate change effects. More specifically, the aim of the work presented here was to: (i) holistically assess how innovation is processed in the indigenous island communities, and (ii) to determine how this innovation process can be enhanced in terms of building resilience in vulnerable communities.

\section{Methodology}

In order to address the aims of this work a number of steps were taken. These included selection of study villages, development of a resilience framework, implementation of the resilience framework in the selected villages and then analysis of the results and further interpretation of potential further resilience opportunities.

\subsection{Study villages and energy systems}

This research presented here elaborates the process and the outcomes of recent off-grid solar systems that have been installed to supply electricity to two Fijian villages. Two villages were selected to be located on the coast so they potentially experience a combination of land and coastal climate change effects. The sites are remote, located a 
small island with no roads and no grid connection to the mainland. The authors engaged closely with the communities of the villages in order to identify some of the subtler socio-cultural resilience's dimensions and values.

The selected sites are two villages which are located in Beqa, a $36 \mathrm{~km}^{2}$ island which is located $10 \mathrm{~km}$ south of the main island of Fiji (Vitu Levu). These two villages, Naceva and Rukua, belong to the Central Division, Rewa Province, Sawau District and while the distance between them is less than $5 \mathrm{~km}$, they can be accessed only by boat. Like most rural Fijian villages, the communities are made up of traditional Pacific Islanders who undertake traditional farming and fishing activities.

Two off-grid solar systems were studied in the selected villages: stand-alone household-level solar units (in Naceva village) and a centralised solar unit with a local grid supplying all village households (in Rukua village). Two different off-grid systems (household- and village-level) were selected in order to compare possible differential dynamics in the innovation process. Innovation in battery energy storage systems and their connectivity to PV panels has made possible the use of energy storage in these villages in order to maintain supply in the evening hours and when there is no adequate sunshine. The Naceva household-level systems were implemented through the Rural Electrification Policy on 15 of the 42 houses of the village. Each participating household had to pay installation fees of FJ \$100 ( USD \$48) and then FJ \$10-20 ( USD \$5-10) each month for the system maintenance. The low number of installations was due to the low number of households that could afford the installation fee. One person was selected from the village to inform the government to come and conduct repairs and collect dues. So far, for the last four months that household solar systems were installed, the community was satisfied from the operation and efficiency of the systems.

In Rukua, the centralised solar project was termed the "Rukua Smart Solar Power project". This installation was a USD $\$ 800,000$ joint initiative between Fiji government and the Inter-Action Corporation of Japan and represented the first solar energy system being built at village level in Fiji. The Rukua system was a $20.5 \mathrm{~kW}$ (108 piece, $190 \mathrm{~W}$ monocrystal) PV solar system with 120kWh valve-regulated lead-acid battery-based (VRLA) storage for 77 households with an installed meter (Interaction Corporation, 2015).

\subsection{Development of a resilience framework}

To assess the contribution of off-grid renewable energy schemes to place-based resilience a renewable energy framework on resilience was created. The main resilience components and dimensions of this framework were identified through a literature review coupled to expert judgement. As electricity access is among the first priority among rural communities and a service for which rural communities are willing to pay (Niez, 2010), we focused on the existence / creation of place-based resilience in relation to energy systems for those communities. To that end a comprehensive review of scientific literature (through Scopus) as well of grey literature was carried out. Rather than a single or composite suite of search terms, a wide range of terms were used to elaborate specific aspects related to resilience accrued from energy systems. This search was carried out until new literature was not providing new information on which to base or modify the existing list of resilience dimensions, suggesting that the resilience dimensions were at least exhaustive.

To structure these various resilience aspects identified from the literature, information was collated into three resilience components which were defined within the context of this study as follows:

Physical energy resilience (PH) - aspects related to the tangible energy system infrastructure function and operation $^{1}$.

\footnotetext{
${ }^{1}$ Linkages between the energy system itself and the disturbances because of the climate change as well as responses need to be understood (Perera, Boyd, Wilkins, \& Itty, 2015) note the little empirical evidence on this issue, while they point out that the lack of this understanding might result in maladaptation.
} 
Socio-ecological resilience (SE) - aspects related to the ability of the individual, communities and socio-cultural assets to be maintained or consensually modified in light of climate change impacts / internally organized structure and architecture to manage/govern affairs ${ }^{2}$.

Institutional-organisational resilience (IO) - externally imposed structure and architecture which positively affect or influence community affairs.

Within those three components, 29 resilience dimensions were identified which were relevant to the studied villages ( 6 for the physical component, 14 for the socio-ecological component and 9 for the institutional-organisational component). The dimensions were based on interpretations of the literature, or in some cases based on expert judgement of the authors (Table 1).

Table 1. The resilience categories / components, dimensions and key references

\section{a) Physical Resilience}

\begin{tabular}{|c|c|c|c|}
\hline Dimension & $\begin{array}{l}\text { Acro } \\
\text { nym }\end{array}$ & Description & Key literature \\
\hline Electricity Systems Reliability & P1 & Need for electricity independency and autonomy & \\
\hline Prevention & $\mathbf{P 2}$ & $\begin{array}{l}\text { Need for measures which will prevent the electricity systems } \\
\text { from breaking down }\end{array}$ & \\
\hline Repair and recovery mechanisms & $\mathbf{P 3}$ & $\begin{array}{l}\text { Need for electricity systems which are of low maintenance } \\
\text { needs }\end{array}$ & \\
\hline Electricity supply flexibility & P4 & Choice between alternative electricity sources & \\
\hline Robustness within financial ROI & P5 & Cost-effectiveness of electricity systems used & \\
\hline $\begin{array}{l}\text { Balance between the use of } \\
\text { natural resources and } \\
\text { infrastructures }\end{array}$ & P6 & $\begin{array}{l}\text { Ability to balance electricity requirements / supply with local } \\
\text { natural resources }\end{array}$ & (DOE-PI; NREL, 2013) \\
\hline
\end{tabular}

\section{b) Socio-ecological resilience}

\begin{tabular}{|c|c|c|c|}
\hline Dimension & $\begin{array}{c}\text { Acron } \\
\text { ym }\end{array}$ & Description & Key literature \\
\hline $\begin{array}{l}\text { Autonomy on decision- } \\
\text { making }\end{array}$ & SE1 & $\begin{array}{l}\text { Autonomy of the community to make and implement } \\
\text { decisions }\end{array}$ & $\begin{array}{l}\text { (Fidelman, Van Tuyen, Nong, } \\
\text { Nursey-Bray, Keoc, \& Owusu, 2016) } \\
\text { (Gawith, Deigneault, \& Brown, 2016) }\end{array}$ \\
\hline Leadership & SE2 & Ability of actors to direct and motivate others to follow & $\begin{array}{l}\text { (Fidelman, Van Tuyen, Nong, } \\
\text { Nursey-Bray, Keoc, \& Owusu, 2016) } \\
\text { (Gawith, Deigneault, \& Brown, } \\
\text { 2016) }\end{array}$ \\
\hline $\begin{array}{l}\text { Risk assessment and } \\
\text { management / Preparedness }\end{array}$ & SE3 & $\begin{array}{l}\text { Ability of communities to assess risks and manage them } \\
\text { in a way to get prepared to meet environmental hazards }\end{array}$ & $\begin{array}{l}\text { (Berke, Chuenpagdee, Juntarashote, \& } \\
\text { Chang, 2008) }\end{array}$ \\
\hline Problem-solving capability & SE4 & $\begin{array}{l}\text { Capability of communities to navigate challenges and/or } \\
\text { draw on traditional knowledge }\end{array}$ & $\begin{array}{l}\text { (Wade, 2003) } \\
\text { (Folke, Resilience: The Emergence of } \\
\text { a Perspective for Social-Ecological } \\
\text { Ssytems Analyses, 2006) }\end{array}$ \\
\hline Learning capacity & SE5 & $\begin{array}{l}\text { Creation of Information Security (through education / } \\
\text { knowledge generation / research). Dissemination and } \\
\text { feedback loops (creation of awareness around RE). }\end{array}$ & (Gupta, et al., 2010) \\
\hline Social Learning & SE6 & $\begin{array}{l}\text { Use of renewable energy for social learning (installed } \\
\text { on schools, hospitals, etc) }\end{array}$ & (Cutter, et al., 2008) \\
\hline Acceptance for innovation & SE7 & $\begin{array}{l}\text { Ability to accept innovative systems (eg watering } \\
\text { systems which can work with solar electricity). }\end{array}$ & $\begin{array}{l}\text { (Gawith, Deigneault, \& Brown, 2016) } \\
\text { Frumhoff et al., } 2015\end{array}$ \\
\hline
\end{tabular}

\footnotetext{
${ }^{2}$ The significance of the link between access to energy and social capital / activities (for instance, "how new incomes generated through provision of energy access are being used, and are the new livelihoods created through provision of energy access impacting existing livelihoods and markets") has been stressed by (Perera, Boyd, Wilkins, \& Itty, 2015) in their review of all literature concerning energy and adaptation.
} 


\begin{tabular}{|l|c|l|l|}
\hline $\begin{array}{l}\text { Ability for transformation / } \\
\text { Paradigm Shift }\end{array}$ & SE8 & $\begin{array}{l}\text { Ability to learn, change systems, and adapt referred } \\
\text { to as 'dynamism' }\end{array}$ & $\begin{array}{l}\text { (Darnhofer, I., 2014) } \\
\text { (Gawith, Deigneault, \& Brown, 2016) }\end{array}$ \\
\hline $\begin{array}{l}\text { Collaboration between } \\
\text { actors (at a community level) }\end{array}$ & SE9 & $\begin{array}{l}\text { Ability of community agents to work together to } \\
\text { improve community resilience }\end{array}$ & $\begin{array}{l}\text { (Ebbin, 2009) } \\
\text { (Berke, Chuenpagdee, Juntarashote, \& } \\
\text { Chang, 2008) }\end{array}$ \\
\hline Health and Well-being & SE10 & $\begin{array}{l}\text { Suitability of the electricity technology to meet health } \\
\text { and well-being living needs of people }\end{array}$ & $\begin{array}{l}\text { (Electric Power Research Institute, } \\
\text { 2009) } \\
\text { (Mala, Schlapfer, \& Pryor, 2009) }\end{array}$ \\
\hline $\begin{array}{l}\text { Livelihood security / } \\
\text { Business resilience }\end{array}$ & SE11 & $\begin{array}{l}\text { Economic activities and development, financial stability } \\
\text { and security, money saving / affordability }\end{array}$ & $\begin{array}{l}\text { (Dornan, M., 2011) } \\
\text { (Mala, Schlapfer, \& Pryor, 2009) }\end{array}$ \\
\hline Routinization of conflict & SE12 & Coping with conflicts & (Ebbin, 2009) \\
\hline Improvisation & SE13 & $\begin{array}{l}\text { Ability to operate a system when no spare parts are } \\
\text { available }\end{array}$ & (Cutter, et al., 2008) \\
\hline $\begin{array}{l}\text { Ownership Management / } \\
\text { Responsibility }\end{array}$ & SE14 & $\begin{array}{l}\text { Level of community's engagement with the solar } \\
\text { systems }\end{array}$ & $\begin{array}{l}\text { (Dornan, M., 2011) } \\
\text { (Ostrom, Gibson, Shivakumar, \& } \\
\text { Andersson, 2001) } \\
\text { (Ostrom, Schroeder, \& Wynne, 1993) }\end{array}$ \\
\hline
\end{tabular}

\section{c) Institutional-organisational resilience}

\begin{tabular}{|c|c|c|c|}
\hline Dimension & $\begin{array}{c}\text { Acron } \\
\text { ym }\end{array}$ & Description & Key literature \\
\hline $\begin{array}{l}\text { Institutional \& Regulatory } \\
\text { nesting and linkages / } \\
\text { Institutional support }\end{array}$ & IO1 & $\begin{array}{l}\text { Need for institutional and regulatory back-up during } \\
\text { demanding circumstances }\end{array}$ & $\begin{array}{l}\text { (Ebbin, 2009) } \\
\text { (Gawith, Deigneault, \& Brown, } \\
\text { 2016) }\end{array}$ \\
\hline $\begin{array}{l}\text { Fit-for purpose mainstreamed } \\
\text { policies, codes and standards }\end{array}$ & IO2 & Compatibility of systems with policy, of systems on-site, etc & (Dornan, M., 2011) \\
\hline $\begin{array}{l}\text { Complementarity / Variety of } \\
\text { electricity strategies (policies) }\end{array}$ & IO3 & $\begin{array}{l}\text { For example how renewable energy can work together with } \\
\text { energy efficiency measures at the community level }\end{array}$ & $\begin{array}{l}\text { (Fidelman, Van Tuyen, Nong, } \\
\text { Nursey-Bray, Keoc, \& Owusu, } \\
\text { 2016) }\end{array}$ \\
\hline $\begin{array}{l}\text { Interconnections between } \\
\text { policies (operational planning) }\end{array}$ & IO4 & $\begin{array}{l}\text { Need for the design of a national system integrating } \\
\text { multiple infrastructures (energy, health, water, etc) }\end{array}$ & $\begin{array}{l}\text { (Ibanez, Gkriza, Mejia-Giraldo, } \\
\text { Krishnan, Mccalley, \& Somani, } \\
\text { 2015) }\end{array}$ \\
\hline $\begin{array}{l}\text { Flexibility on decision-making } \\
\text { regarding electricity affairs }\end{array}$ & IO5 & $\begin{array}{l}\text { Need for decision-making flexibility necessary (eg. Oil } \\
\text { prices fluctuations or/and to avoid bureaucratic problems). }\end{array}$ & (Dornan, M., 2011) \\
\hline $\begin{array}{l}\text { Monitoring (and data } \\
\text { collection?) \& Reporting }\end{array}$ & IO6 & $\begin{array}{l}\text { Government request to the Community to address quality } \\
\text { control problems through consistent monitoring, } \\
\text { measurement, data collection and reporting }\end{array}$ & $\begin{array}{l}\text { (DOE-PI; NREL, 2013) } \\
\text { (Dornan, M., 2011) }\end{array}$ \\
\hline $\begin{array}{l}\text { Prevention (from the } \\
\text { Governmental side) }\end{array}$ & IO7 & $\begin{array}{l}\text { The intervention from the Government so as communities } \\
\text { are more prepared to respond to environmental hazards }\end{array}$ & $\begin{array}{l}\text { (Electric Power Research } \\
\text { Institute, 2009) } \\
\text { (Miara, Vorosmarty, Wollheim, } \\
\text { \& Rosenzweig, 2013) }\end{array}$ \\
\hline Engagement in national debate & IO8 & $\begin{array}{l}\text { Degree to which the community feels engaged to the } \\
\text { national debates on energy / climate change }\end{array}$ & \\
\hline $\begin{array}{l}\text { Cohesion between community } \\
\text { and government }\end{array}$ & IO9 & $\begin{array}{l}\text { The tendency of the community to align with government's } \\
\text { pursuits }\end{array}$ & (Alchian \& Demsetz, 1972) \\
\hline
\end{tabular}

Each dimension was scored using a four point Likert scale reflecting the extent to which the energy system intervention had led to an increase in resilience compared to the situation prior to the intervention. The scoring system was zero ("-") when there was no discernible effect of the energy system intervention on that particular resilience dimension, " $x$ ' with a negligible increase, " $x x^{\prime}$ " with a medium-level increase and " $x x x^{\prime}$ " with a significant improvement reflecting the maximum attainable in that resilience dimension. The intent of the scoring system was to help identify the indicative portfolio of effects that the energy system intervention had on the village level resilience of the targeted communities.

\subsection{Application of the resilience framework}

The two village chiefs were contacted by a local agent (born and living in Naceva village) to facilitate arrangements for a discussion with the community. For Naceva this involved a visit to the village and a whole-of-village meeting with the traditional "sevusevu" respect offering of cava roots. This meeting was carried out using a Fijian translator for a majority of the discussions. For Rukua, meeting in the village was not an option as the community was too busy, thus a delegation was sent from the village to Lawaki Resort for a formal meeting. The delegation consisted of 
the village chief, two village elders and the designated community solar officer who was the individual selected to collect solar electricity dues with the provincial government office and report any maintenance or repairs. As all the Rukua delegations were competent English speakers, this interview was carried out without a translator.

The resilience framework was unpacked into a number of questions pertaining to each dimension and this was then used to guide the discussion in both villages to ensure coverage was achieved of all dimensions. Traditional proceedings and interviews lasted $2-3$ hours. Following the interviews and during the analysis stage, further questions were asked to validate the correctness and completeness of information this was through telephone or email communications with identified local people.

\section{Results}

\subsection{Assessing village-level resilience}

The level of resilience on the established Likert scale for each dimension was assessed by the authors based on the interviews in the two villages. The answers from the interviews provided insights on how the projects scored on the resilience dimension and also offered a broader understanding onhow the projects have failed. The assessment of answers was primarily carried out by consensus between the two authors involved in the interviews and using the third author as a further independent source for verification. Table 2 presents the scoring and justification. This data demonstrates both similarities and differences in the place-based resilience portfolio for these neighbouring villages in relation to the use of renewable energy systems.

Table 2. The resilience dimensions of Naceva and Rukua village. Scoring: from "-" (= no resilience) to "XXX" (=high resilience)

\section{a) Physical resilience}

\begin{tabular}{|l|c|c|l|}
\hline \multicolumn{1}{|c|}{$\begin{array}{c}\text { RESILIENCE } \\
\text { DIMENSION }\end{array}$} & $\begin{array}{l}\text { NACEVA } \\
\text { VILLAGE }\end{array}$ & $\begin{array}{c}\text { RUKUA } \\
\text { VILLAGE }\end{array}$ & \multicolumn{1}{c|}{ COMMENTS } \\
\hline $\begin{array}{l}\text { PH1: Electricity } \\
\text { Systems Reliability }\end{array}$ & $\mathrm{XXX}$ & $\mathrm{X}$ & $\begin{array}{l}\text { The solar system at Naceva is too new to allow reliability assessment but no issues were } \\
\text { reported and construction appeared sound. The system at Rukua is partially not working for } \\
\text { over 5 months maybe due to TC Winston cyclone impacts. }\end{array}$ \\
\hline $\begin{array}{l}\text { PH2: Prevention of } \\
\text { electricity systems } \\
\text { breaking down }\end{array}$ & - & $\mathrm{X}$ & $\begin{array}{l}\text { Repair reports are addressed to the Government. There is no prevention policy foreseen from } \\
\text { the Government. Both villages host "reporting persons" (individuals whose main responsibility } \\
\text { is the monitoring of solar system and the problem reporting; however, there is no training on } \\
\text { prevention processes or /and repairs). }\end{array}$ \\
\hline $\begin{array}{l}\text { PH3: Repair and } \\
\text { recovery } \\
\text { mechanisms }\end{array}$ & $\mathrm{X}$ & $\mathrm{X}$ & $\begin{array}{l}\text { Naceva submits fees and damages report each six months to government. Rukua has a repair } \\
\text { agreement with the government for the first 5 years of operation but the government } \\
\text { responds slowly. }\end{array}$ \\
\hline $\begin{array}{l}\text { PH4: Electricity } \\
\text { supply flexibility }\end{array}$ & $\mathrm{XX}$ & $\mathrm{XX}$ & $\begin{array}{l}\text { Both villages have as fall-back stand-alone household generators as well as independent solar } \\
\text { lights, and kerosene lamps. }\end{array}$ \\
\hline $\begin{array}{l}\text { PH5: Robustness } \\
\text { within financial ROI }\end{array}$ & $\mathrm{XXX}$ & $\mathrm{XXX}$ & $\begin{array}{l}\text { Systems are mainly paid for by external funds, contributions by villagers were minimal so the } \\
\text { household / village ROI is very high. }\end{array}$ \\
\hline $\begin{array}{l}\text { PH6: Balance } \\
\text { between the use of } \\
\text { natural resources } \\
\text { and infrastructures }\end{array}$ & $\mathrm{X}$ & $\mathrm{X}$ & $\begin{array}{l}\text { The link identified between infrastructures is limited. Rukua did identify that there is } \\
\text { inadequate water volume and consistency for small hydroelectric scheme; Naceva confirmed } \\
\text { that there is adequate water volume for a small hydroelectric scheme. }\end{array}$ \\
\hline
\end{tabular}

\section{b) Socio-ecological resilience}

\begin{tabular}{|l|c|c|l|}
\hline $\begin{array}{l}\text { RESILIENCE } \\
\text { DIMENSION }\end{array}$ & $\begin{array}{l}\text { NACEVA } \\
\text { VILLAGE }\end{array}$ & $\begin{array}{c}\text { RUKUA } \\
\text { VILLAGE }\end{array}$ & COMMENTS \\
\hline $\begin{array}{l}\text { SE1: Autonomy on } \\
\text { decision-making }\end{array}$ & $\mathrm{XXX}$ & $\mathrm{XXX}$ & $\begin{array}{l}\text { Both villages have traditional communal decision making process informing the Chief through } \\
\text { regular meetings. }\end{array}$ \\
\hline SE2: Leadership & $\mathrm{X}$ & $\mathrm{XX}$ & $\begin{array}{l}\text { Both villages displayed strong leadership in obtaining energy systems but negligible leadership } \\
\text { displayed in allocation use of electricity at household level. }\end{array}$ \\
\hline
\end{tabular}




\begin{tabular}{|c|c|c|c|}
\hline $\begin{array}{l}\text { SE3: Risk assessment } \\
\text { and management }\end{array}$ & $\mathrm{X}$ & $\mathrm{XX}$ & $\begin{array}{l}\text { Naceva has no plans for disaster situations just report renewable energy problems every } 6 \\
\text { months. Rukua has good disaster planning but limited energy risk management beyond battery } \\
\text { replacement fund. }\end{array}$ \\
\hline $\begin{array}{l}\text { SE4: Problem-solving } \\
\text { capability }\end{array}$ & $\mathrm{X}$ & $\mathrm{XX}$ & $\begin{array}{l}\text { Both communities are aware of the process on how to problem-solve but rely only on third } \\
\text { parties; Rukua has identified one person who should be responsible to report problems. }\end{array}$ \\
\hline $\begin{array}{l}\text { SE5: Learning } \\
\text { capacity }\end{array}$ & $\mathrm{X}$ & $\mathrm{XX}$ & $\begin{array}{l}\text { Both communities have now better information (TV, internet) for learning on disaster warning } \\
\text { and energy efficiency. Naceva have minimal interest in learning about energy systems but } \\
\text { Rukua is interested in energy system functioning and basic maintenance. }\end{array}$ \\
\hline SE6: Social Learning & - & - & $\begin{array}{l}\text { There is no social learning in place. Energy is perceived as a household and not a community } \\
\text { issue. Solar systems are not connected to public buildings; except one church in Rukua, which } \\
\text { allows parishioners to listen to rugby on their headphones while attending the mass. }\end{array}$ \\
\hline $\begin{array}{l}\text { SE7: Acceptance for } \\
\text { innovation }\end{array}$ & $\mathrm{XX}$ & $\mathrm{XX}$ & $\begin{array}{l}\text { Communities are willing to accept innovation if this comes for free; however there is limited } \\
\text { willingness to invest even minimal contributions if there is the slightest risk incorporated to } \\
\text { this new technology. }\end{array}$ \\
\hline $\begin{array}{l}\text { SE8: Ability for } \\
\text { transformation / } \\
\text { Paradigm Shift }\end{array}$ & - & - & $\begin{array}{l}\text { There is minimal evidence of paradigm shift or any intention; the focus is on making life more } \\
\text { comfortable with TVs and phone chargers. There is no thought of economic opportunities. }\end{array}$ \\
\hline $\begin{array}{l}\text { SE9: Cooperation/ } \\
\text { collaboration } \\
\text { between actors }\end{array}$ & $\mathrm{XX}$ & $\mathrm{XX}$ & $\begin{array}{l}\text { Chief acts as village representative to government (iTaukieiaffairs) and is informed by regular } \\
\text { village meetings. There is involvement of NGOs in non-energy activities e.g. marine protection. }\end{array}$ \\
\hline $\begin{array}{l}\text { SE10: Health and } \\
\text { Well-being }\end{array}$ & $\mathrm{X}$ & $\mathrm{XX}$ & $\begin{array}{l}\text { Improved well-being as feel better informed of disaster risks and more in touch (TV, Facebook } \\
\text { etc.). Both Naceva and Rukua note the less kerosene fire risk and the fact that children can } \\
\text { study during evenings. But neither direct health nor improved resilience, through dedicated } \\
\text { community energy use for food and medicine storage etc., was noted. }\end{array}$ \\
\hline $\begin{array}{l}\text { SE11: Livelihood } \\
\text { security / business } \\
\text { resilience }\end{array}$ & $\mathrm{X}$ & $\mathrm{X}$ & $\begin{array}{l}\text { There is no consideration of energy as a promoter of economic activity; however the benefit } \\
\text { for reduced costs for petrol for generators and kerosene for lights has been emphasized by } \\
\text { both Naceva and Rukua. }\end{array}$ \\
\hline $\begin{array}{l}\text { SE12: Routinization } \\
\text { of conflict }\end{array}$ & - & - & $\begin{array}{l}\text { There is minimal intra-village conflict and traditional mechanisms are employed. In Rukua, the } \\
\text { overuse of energy by households was blamed on the government for not repairing the system, } \\
\text { rather than individual households. }\end{array}$ \\
\hline SE13: Improvisation & - & - & Both villages wait for help and no improvisation ability was noted in relation to energy. \\
\hline $\begin{array}{l}\text { SE14: Ownership } \\
\text { Management / } \\
\text { Responsibility }\end{array}$ & - & $x$ & $\begin{array}{l}\text { In Naceva all ownership and responsibility is devolved to the government. In, Rukua, the } \\
\text { situation is similar except for the metering system which aims to permit community-funded } \\
\text { battery replacement after } 5 \text { years. }\end{array}$ \\
\hline
\end{tabular}

\section{c) Institutional-organisational resilience}

\begin{tabular}{|c|c|c|c|}
\hline $\begin{array}{l}\text { RESILIENCE } \\
\text { DIMENSION }\end{array}$ & $\begin{array}{l}\text { NACEVA } \\
\text { VILLAGE }\end{array}$ & $\begin{array}{l}\text { RUKUA } \\
\text { VILLAGE }\end{array}$ & COMMENTS \\
\hline $\begin{array}{l}\text { IO1: Institutional \& } \\
\text { Regulatory nesting and } \\
\text { linkages }\end{array}$ & $\mathrm{X}$ & $\mathrm{XX}$ & $\begin{array}{l}\text { Both villages are aware that renewable energy was implemented through the Rural } \\
\text { Electrification Policy. Rukua involved both the Fiji Prime Minister and subsequently the } \\
\text { Japanese Ambassador in Fiji to obtain the system. }\end{array}$ \\
\hline $\begin{array}{l}\text { 102: Fit-for purpose } \\
\text { mainstreamed policies, } \\
\text { codes and standards }\end{array}$ & $\mathrm{XX}$ & - & $\begin{array}{l}\text { In Naceva the household systems seem to be fit-for-purpose. In Rukua, the system is partially } \\
\text { broken down and unrepaired for months so maintenance standards are inadequate. }\end{array}$ \\
\hline $\begin{array}{l}\text { IO3: Complementarity / } \\
\text { Variety / Diversification } \\
\text { of electricity strategies }\end{array}$ & $\mathrm{X}$ & - & $\begin{array}{l}\text { In Naceva, there is basic of awareness of energy efficiency on household system. In Rukua, } \\
\text { there is no control or awareness on energy use and nature of energy supply. }\end{array}$ \\
\hline $\begin{array}{l}\text { I04: Interconnections } \\
\text { between policies }\end{array}$ & - & - & There is no evidence of interconnections. \\
\hline $\begin{array}{l}\text { 105: Flexibility on } \\
\text { decision-making } \\
\text { regarding electricity } \\
\text { affairs }\end{array}$ & - & $\mathrm{XX}$ & $\begin{array}{l}\text { Government decides, pays and owns energy systems in both villages with minimal } \\
\text { engagement from the villages. However, government responded and delivered to the energy } \\
\text { needs of Rukua as stated by Chief, even if went through a foreign party. }\end{array}$ \\
\hline $\begin{array}{l}\text { I06: Monitoring (and } \\
\text { data collection?) \& } \\
\text { Reporting }\end{array}$ & $\mathrm{X}$ & $\mathrm{x}$ & $\begin{array}{l}\text { The technical monitoring is limited to registration of problems and call for repairs. In Rukua, } \\
\text { there is village-level monitoring of usage solely for purposes of charging households for battery } \\
\text { replacement. }\end{array}$ \\
\hline $\begin{array}{l}\text { 107: Prevention (from } \\
\text { the Governmental side) }\end{array}$ & - & $\mathrm{x}$ & $\begin{array}{l}\text { The Chief of Rukua has been trained in disaster prevention for his village and has a } \\
\text { preparation plan. }\end{array}$ \\
\hline $\begin{array}{l}\text { IO8: Engagement in } \\
\text { national debate }\end{array}$ & - & $\mathrm{XX}$ & $\begin{array}{l}\text { Rukua representatives are knowledgeable on climate change, coastal protection and marine } \\
\text { resources. However, there is no link made between the village energy system and climate } \\
\text { change. This is reported through the Provincial meetings that the Chief attends. }\end{array}$ \\
\hline $\begin{array}{l}\text { I09: Cohesion between } \\
\text { community }\end{array}$ & $\mathrm{X}$ & $\mathrm{XX}$ & $\begin{array}{l}\text { In Naceva, there are minimal links with government. In Rukua, the Chief is a representative on } \\
\text { the Provincial Committee for Rewa province and Ministry of i-Taukei Affairs although this does } \\
\text { not seem to affect maintenance schedule by other government departments. }\end{array}$ \\
\hline
\end{tabular}


When it comes to physical resilience ( $\mathrm{PH}, \underline{\text { Table } 2 \mathrm{a}})$, most noticeable is the high score for the financial robustness of the system (dimension PH5); the high score is related to the negligible contribution for the household system in Naceva (USD \$48 overall installation charge per household) and the system provided for free in Rukua. For socioecological resilience (SE, Table $2 \mathrm{~b}$ ), there is an existing traditional community-based system (in which regular village assemblies provide guidance to the chief); this system contributes to the high level of SE1 (decision-making). These village-level established processes also seem to contribute to many other of the SE dimensions. However, the energy system intervention did not have any impacts on SE6 (social learning), SE12 (conflict resolution), SE13 (improvisation) and it also had limited influence on livelihood/ business resilience. The institutional-organizational (IO) scorings (Table 2c) were quite different between the two villages. In Naceva the household level renewable energy system seemed to contribute to resilience (e.g. IO1 - IO3), whereas in Rukua the system was neither considered as fit-for-purpose or complementary to other energy systems (IO2 - 4). The higher levels of dimensions IO5 - 9 in Rukua reflected strong external engagement, especially with the government; the Rukua village chief and elders were well informed and were involved in the provincial and national debate on sustainability.

The initial conclusions from this analysis is that the solar system has provided additional resilience to the village in the $\mathrm{PH}, \mathrm{SE}$ and $\mathrm{IO}$ dimensions, although there were some differences between the villages partly related to the type of implementation of the solar system (household stand-alone applications in the one village, central solar system in the other village). However, from the interviews further dynamics were identified especially in the village-wide energy system in Rukua. The system in Rukua was implemented through Japanese development assistance with what appears to be minimal discussion with the village beyond the request by the chief to the Prime Minister. There was no evidence that the solar system that has been implemented was designed to meet the needs of the village, beyond calculation of the number of households to connect. Positioning such modern innovative technology in a traditional village had a number of largely undesirable connotations beyond those identified by the resilience dimensions:

"Tragedy of the commons" - Rukua village was told by the solar system installers that they could run no more than 3 fridges so as not to drain the system. There appeared to be no internal discussion or external designation of who or where these fridges would be placed; therefore, the villagers purchased 30 fridges which - when connected - drained the electricity supply once it was running on battery after sunset. Due to the lack of any organisation about use of the energy, the village exhibited a "tragedy of the commons" (Ostrom, E., 2015) in which each household tried to maximise its benefit from a finite resource.

Unsustainably low tariff setting - each household was metered for its electricity use and charged at a set rate and payments were made monthly. The rate was estimated based on collection of adequate money to replace the batteries after 5 -years of use. This per unit rate was low as it did not include any re-payment of the installed renewable energy equipment and supply system or for the system maintenance. This was a facilitating factor in the "tragedy of the commons" as the unit price did not limit usage and failed to promote any attention to energy efficiency and conservation. In addition, in financial terms, the energy system has not proved sustainable, as electricity usage charges only covered battery replacement and not equipment maintenance and repair.

Increased fossil fuel use - after the implementation of the solar system, and following the lack of repair of the system in 2016, subsequent daily electricity draining of the batteries led to 6 households starting to run fuel generators once the supply was run down, each of which consumed 20 litres per week making a village total of approximately 120 litres per week. Previously, when the village was connected to a central generator for daily electricity supply from $18 \mathrm{~h} 00$ to $21 \mathrm{~h} 00$, the usage was 40 litres per week. This means that, according to these figures 
from the village, Rukua is now using about three times the amount of fossil fuel for electricity that was used prior to installation of the renewable energy system.

Implementation of the energy system in Rukua thus seems to have inspired an energy "rush" which led to a "tragedy of the commons", lack of regard for energy efficiency due to low pricing of electricity and overall an increased fossil fuel use. In Naceva, the system was household-based and thus not a common resource at the village level; meaning that a "tragedy of the commons" situation could not occur. Fixed, regular payments were submitted as rent for the installed system rather than for units of electricity used. Households self-limited their usage to whatever was generated / stored through use of appropriate appliances (e.g. LED lights, mobile phone chargers) obviating the need for additional fossil fuel generators.

\subsection{Designing innovative interventions for resilience}

It is clear that both the Naceva and Rukua systems have brought resilience benefits such as strengthening the community-level decision making process, enhancing links to the governmental system and improved communications in disaster situations (Table 2). However, it also appeared that the energy systems were minimally embedded in the respective communities. Discussions on how to use the renewable energy for economic benefit, supporting new livelihood activities or for communal services (such as communal fridges for storage of fish catch) did not happen. The energy provided for more comfortable living (e.g. lights and mobile phones) rather than as an instigator for enhancing livelihood sustainability, growing economic benefits or more resilient development (Zafirakis, et al., 2014). It was concluded from this analysis that there were missed opportunities in the way that the installations were carried out in terms of building village-level resilience.

Consequently, based on the resilience portfolio for Naceva and Rukua, we designed a model of intervention which could potentially build further resilience in these communities on the back of the renewable energy installation. The model was based on expert consensus of the authors and used as an indicative demonstration of what further resilience could be captured in lieu of possibilities for practical experimentation. The focus of the intervention was to strengthen the linkage between the installed RE technology and society. The proposed interventions covered the areas of energy maintenance, management and monitoring (termed the MMM intervention hereafter). We have identified a set of tasks which could further furnish the villages with improved resilience, as explained through the resilience framework (Table 3).

Table 23. Proposed additional interventions to promote further resilience through the RE systems of Rukua and Naceva and the (positive) effects on resilience framework.

\begin{tabular}{|c|c|c|}
\hline Intervention & Description & Primary effects \\
\hline \multicolumn{3}{|c|}{ MANAGEMENT } \\
\hline $\begin{array}{l}\text { 1. Assessment (and } \\
\text { update) of energy } \\
\text { infrastructure }\end{array}$ & $\begin{array}{l}\text { Looking for possibilities for use of battery storage or/and micro-grids, micro } \\
\text { wind-generators etc. (as more energy choices means more resilience). } \\
\text { Innovative energy storage technologies have been investigated by authors as } \\
\text { means of coping with wind or solar energy intermittency (Zafirakis \& Chalvatzis, } \\
\text { 2014). }\end{array}$ & $\begin{array}{l}\text { PH1, PH2, PH4, PH6, SE7, } \\
\text { SE8, SE13,SE14, IO3, IO4, } \\
\text { IO5 }\end{array}$ \\
\hline $\begin{array}{l}\text { 2.Increase of information } \\
\text { incoming \& relevant } \\
\text { discussion in the villages }\end{array}$ & $\begin{array}{l}\text { For example, Information on the creation of links of electricity access to other } \\
\text { economic developments (tourism, fishing, trade, electricity business, etc). }\end{array}$ & $\begin{array}{l}\text { PH6,SE4, SE6, SE8, SE11, } \\
\text { SE12, SE14 }\end{array}$ \\
\hline $\begin{array}{l}\text { 3.Community Energy } \\
\text { management }\end{array}$ & $\begin{array}{l}\text { Creation of an agreed community approach to management of solar resource } \\
\text { and exploitation rights and compliance measures within the traditional village } \\
\text { leadership governance structure. }\end{array}$ & $\begin{array}{l}\text { PH1, PH2, PH6, SE1, SE3, } \\
\text { SE4, SE6, SE9, SE12, SE14, } \\
\text { IO5, IO6, IO9 }\end{array}$ \\
\hline $\begin{array}{l}\text { 4.Development of } \\
\text { participatory future } \\
\text { scenarios }\end{array}$ & $\begin{array}{l}\text { Development of participatory scenarios for future optimisation of community } \\
\text { and individual wellbeing benefits and possible innovation-based paradigm shifts } \\
\text { with wide community engagement and the facilitate decision making to a } \\
\text { consensual future trajectory Action Plan. }\end{array}$ & SE6, SE7, SE4, SE8, SE11 \\
\hline 5. Reporting & $\begin{array}{l}\text { Development of a village system for recording energy usage and assessment of } \\
\text { benefits in relation to government policy objectives }\end{array}$ & $\begin{array}{l}\text { PH3, PH5, SE1, SE4, SE5, } \\
\text { SE9, SE12, SE14, IO2, IO3, } \\
\text { IO4, IO6 }\end{array}$ \\
\hline
\end{tabular}




\begin{tabular}{|c|c|c|}
\hline $\begin{array}{l}\text { 6. Enhancement of } \\
\text { collaboration with } \\
\text { government }\end{array}$ & $\begin{array}{l}\text { Closer interaction with the government, for example, through communication } \\
\text { of data collected through monitoring of OGSS (see monitoring process } \\
\text { recommended above). Participation of communities at local energy planning } \\
\text { performed by the Government and in Committees concerning the outcomes of } \\
\text { OGSS implementation or (for example) to securing long-term maintenance } \\
\text { funding. }\end{array}$ & $\begin{array}{l}\mathrm{PH} 3, \mathrm{SE} 4, \mathrm{IO} 1, \mathrm{IO} 2, \mathrm{IO}, \\
\mathrm{IO}, \mathrm{IO}, \mathrm{IO9}\end{array}$ \\
\hline $\begin{array}{l}\text { 7.Introduction to energy } \\
\text { saving measures }\end{array}$ & $\begin{array}{l}\text { Measures for increase of electricity supply to be accompanied by reduction of } \\
\text { electricity demand (through energy saving measures). Government should } \\
\text { make sure that all households comply with best-practice energy efficiency } \\
\text { standards and practices. }\end{array}$ & $\begin{array}{l}\text { PH4, PH6, SE7, SE8, SE10, } \\
\text { SE11, SE13, IO3, IO4, IO5 }\end{array}$ \\
\hline \multicolumn{3}{|c|}{ MAINTENANCE } \\
\hline $\begin{array}{l}\text { 8.Use of standard OGSS } \\
\text { spare parts components }\end{array}$ & $\begin{array}{l}\text { Use of standard OGSS spare parts components (batteries, inverters, controllers, } \\
\text { etc.) which can accelerate the technical intervention from the Government and } \\
\text { can create a local pool of know-how. }\end{array}$ & $\begin{array}{l}\text { PH1, PH3, SE3, SE5, SE13, } \\
\mathrm{IO2}\end{array}$ \\
\hline 9.On-site learning process & $\begin{array}{l}\text { Introduction of training courses on a) technical OGSS aspects, such as cleaning } \\
\text { PV modules, checking batteries, collecting electricity fees, replacing fuses and } \\
\text { fixing disconnected wires, b) links between electricity supply and other } \\
\text { economic activities, c) monitoring, assessment and reporting OGSS outcomes } \\
\text { (fault diagnostics etc). Local training should include any present or future } \\
\text { auxiliary equipment (such as batteries, etc.) in case the OGSS needs expansion / } \\
\text { adjustment to new environment. Learning should be problem-based. }\end{array}$ & $\begin{array}{l}\text { PH1, PH2, PH3, SE3, SE4, } \\
\text { SE5, SE6, SE8, SE9, SE11, } \\
\text { SE13, SE14, IO2, IO6 }\end{array}$ \\
\hline \multicolumn{3}{|c|}{ MONITORING } \\
\hline $\begin{array}{l}\text { 10.Demonstration of the } \\
\text { OGSS projects }\end{array}$ & $\begin{array}{l}\text { Demonstration of the OGSS operation \& maintenance, for example, to the } \\
\text { youth of the village. }\end{array}$ & PH3, SE5, SE6,SE7 \\
\hline $\begin{array}{l}\text { 11.Exchange of lessons } \\
\text { learnt between villages }\end{array}$ & $\begin{array}{l}\text { Exchange of lessons learnt through discussions, exchange of visits to OGSS etc. } \\
\text { Need emphasized from (New Zealand Government, 2016) and (Niez, 2010). }\end{array}$ & $\begin{array}{l}\text { PH3, SE3, SE4, SE5, SE6, } \\
\text { SE9 }\end{array}$ \\
\hline $\begin{array}{l}\text { 12. Constant OGSS } \\
\text { environmental assessment }\end{array}$ & $\begin{array}{l}\text { Looking for possible impacts from the use of OGSS or/and batteries (as battery } \\
\text { leaks might be a very serious environmental problem once occurred). }\end{array}$ & PH2, PH6, SE3, IO6 \\
\hline $\begin{array}{l}\text { 13.Financial assessment of } \\
\text { the OGSS \& constant } \\
\text { update }\end{array}$ & $\begin{array}{l}\text { For example (if systems would come with batteries), financial assessment of } \\
\text { battery sizing which is considered as "key" to achieving the most economical } \\
\text { arrangement out of OGSS (Agence Francaise et Developpement, 2014)³. }\end{array}$ & $\begin{array}{l}\text { PH3, PH6, SE3, SE4, SE10, } \\
\text { SE14, IO6, IO7 }\end{array}$ \\
\hline $\begin{array}{l}\text { 14.Optimization of the } \\
\text { metering system }\end{array}$ & $\begin{array}{l}\text { Request from the Government of a study on the best rural metering strategies } \\
\text { at a global level (Niez, 2010). Villages should make sure that payments are all } \\
\text { made as this demonstrates a fully reliable electricity system which is promising } \\
\text { in terms of future profits (as might attract investors for further expansions). }\end{array}$ & $\begin{array}{l}\text { PH1, PH5, SE1, SE11, IO2, } \\
\text { IO6 }\end{array}$ \\
\hline
\end{tabular}

Based on the developed understanding of the village systems, we have theoretically applied the MMM-interventions to the existing situation in both villages and then we have assessed the projected effect on the resilience portfolio (Figure 1). For both Naceva and Rukua, an increase in resilience was indicated in many PH, SE and IO resilience dimensions because of the MMM intervention.

\section{Figure 1. The baseline village resilience dimensions (black) with the additional resilience benefits (grey) from the proposed intervention}

\section{Naceva}

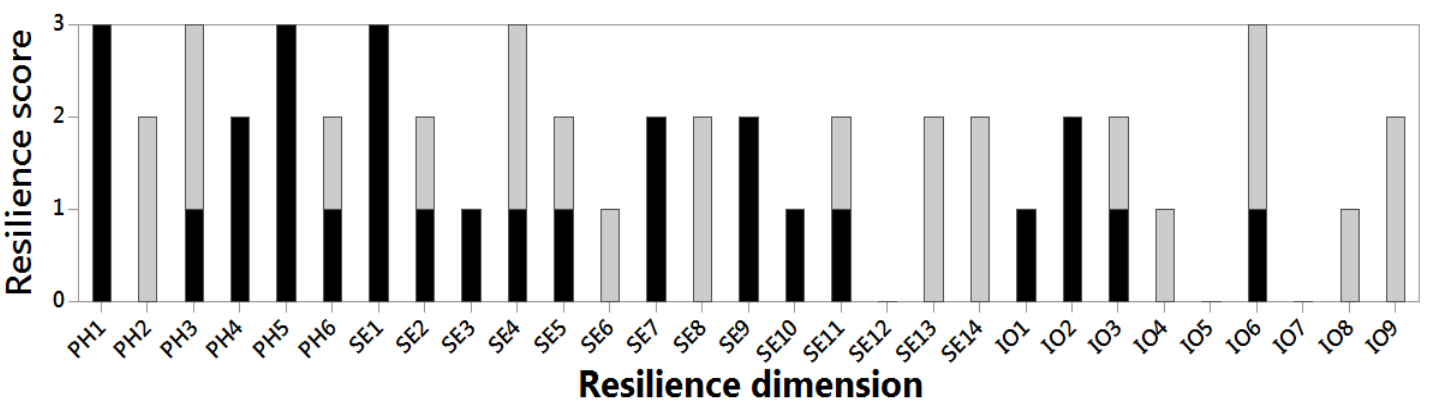

\footnotetext{
${ }^{3}$ If too many batteries are installed, the investment has no or limited savings over the period compared to the diesel solution. If, on the other hand, there are too few batteries, this would cause the diesel component to start too frequently, reducing the achieved efficiency and savings.
} 


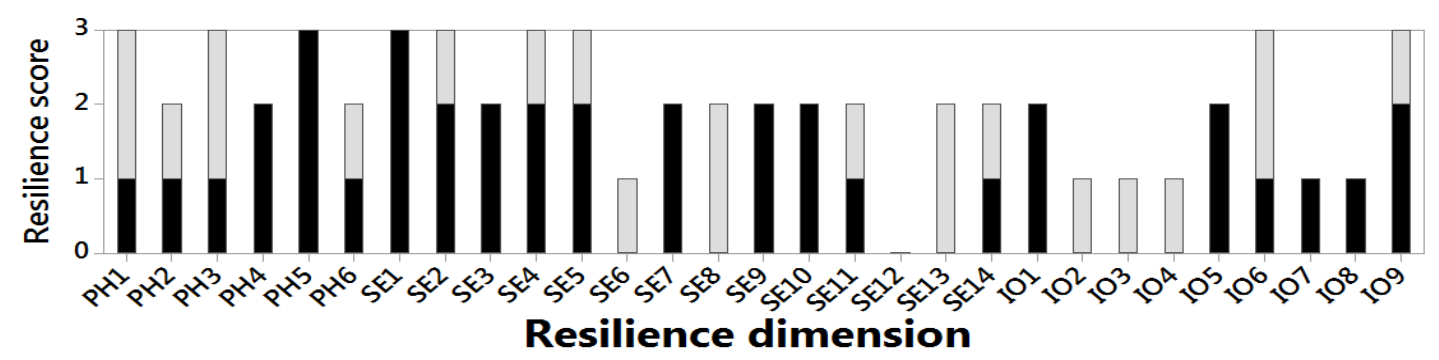

The indicative increases in resilience through the additional MMM interventions suggest that the way the solar systems were initially implemented missed opportunities for building resilience. The additional MMM intervention helped strengthen the interface between society and technology. This is particularly the case for SE8 (paradigm shift), SE13 (improvisation) and SE14 (ownership) which were low in the surveyed situation but which would likely be strengthen using the MMM intervention. This indicative analysis demonstrates the potential for building further resilience through interventions which would shift the focus on the interaction between technology and society.

\section{Discussion}

\subsection{Technologies and community resilience}

Vulnerability has been described as " $a$ bridge that connects the physical impacts of climate to adaptations in socialecological systems" (Malone \& Engle, 2011). The impacts of extreme conditions on quality of life, energy consumption and health of communities have been studied by the scientific community, e.g. (Santamouris \& Kolokotsa, 2015) and building resilience concerns creating positive outcomes despite high-risk status (Eells, 2016). Immense efforts are undertaken on modelling future climate projects, such as the global IPCC and Pacific region (Australian Aid, 2011) and then promoting strategic and operational responses within government and private sector. However, sometimes, regional and national umbrellas prove limited in their scope of dealing with local renewable energy issues (Michalena \& Hills, 2012); and downscaling of these futures to a spatial scale relevant to local-level vulnerability and construction of place-based resilience remains challenging. Thus, creating communities that are able to make decisions will strengthen their adaptive capacity and flexibility and comprehensively respond to the uncertainty of climate change remains a priority at a local scale.

Community resilience has been touted as a key strategy for managing increased disaster risk under climate change e.g. (Tompkins, E.L. \& Adger, 2004); (Nelson, 2011) (Wise, et al., 2014). One determinant of resilience is choices made at the household level, for example through personal lifestyle choices, behaviour and willingness to support climate change policy initiatives (Elrick-Barr, Thomsen, Preston, \& Smith, 2016b) or by simply "using challenges for growth to make future hardships more manageable" (Eells, 2016). The household as a boundary of activity is relevant to indoors activity and the role of appliances and behaviour to energy consumption (Pothitou, Hanna, \& Chalvatzis, 2016) (Pothitou, Hanna, \& Chalvatzis, 2017). To increase resilience, communities need to increase adaptive capacity, although the specific degree to which the household is a venue for adaptive action remains largely unclear (Wamsler \& Brink, 2014) (Hughes \& Sarzynski, 2015). In this process of increasing adaptive capacity the need for enhancement of social capital has been suggested by authors (Gawith, Deigneault, \& Brown, 2016). Enhanced social capital turns "disaster stricken communities into active participants, rather than vulnerable communities at a state of helplessness" (Berke, Chuenpagdee, Juntarashote, \& Chang, 2008).

In the case of PSIDS, community resilience tends to be strongly correlated with economic resources (Manyena, 2006). This linkage between economic development and resilience would seem to be a strong driver behind rural electrification as spelled out by the Fijian Prime Minister at Rukua. However, the socio-economic characteristics of rural Pacific communities seem to leave little room for cost effectiveness when it comes to electrification. In Fiji, 
large subsidies of up to $95 \%$ of the cost from the government to cover renewable energy installation and minimal and problematic fee collection (Republic of Fiji, 2014) means that substantial community benefits are required to justify such investment. This situation emphasises the need for innovations to be holistically planned and implemented to optimise development benefits; the cases presented in this paper demonstrate weaknesses in contextualising the innovation and thus erosion of resilience benefits.

Authors have identified concerns with technological innovations that are promoted to deal with contemporary challenges but presented as top-down and "prepackaged" approaches with little empathy for the societal context (e.g. (Smith, Fressoli, \& Thomas, 2014). Furthermore, other authors note that the "whole notion of technology being transferred and embedded as a package into a conforming recipient context begins to look problematic" and thus the need to develop analyses which contribute to understanding of the socio-technical context (Geels, 2004) (Geels \& Kemp, 2007), (Bryne, Smith, Watson, \& Ockwell, 2011). For the Pacific, in which the largest sector for inward climate change development assistance is renewable energy (Atteridge \& Canales, 2017), and which has over USD 1 billion of pledges predominantly for renewable energy (New Zealand Government, 2016), the analysis presented in this work points to a necessity for further research to enhance contextualisation of energy innovations to accrue resilience gains.

\subsection{Building resilience through renewable energy innovation}

International and national interests in climate change in the Pacific are high with significant inward investment in both mitigation and adaptation. The "Mega-What" question whether "renewable energy is finally for people or for Feed-In-Tariffs, trade and targets" (Hills \& Michalena, 2013) has preoccupied researchers. With a lens on rural communities, the work presented here aimed to promote an innovative approach in the implementation of off-grid renewable energy schemes. Using a resilience framework made up of physical, socio-ecological and institutional dimensions, results from two Fijian sites demonstrated that the increased electricity supply through renewable energy does lead to some resilience gains but that there are considerable missed opportunities for further gains which had not been explored or exploited. If it is agreed that "renewable energy governance might block the technically feasible" (Michalena \& Hills, 2013b), the here analysis suggested that these further resilience gains could be captured through additional interventions which strengthen the socio-technological interface.

In both cases of Rukua and Naceva, there has been no evidence that the implemented innovations have succeeded to meet the resilience building needs of the village. In Rukua, for example, quick recovery and restoration of systems to normal operating state (Khodaei, 2014) was not achieved and a partial operating system was unrepaired for months. Although, it is argued that RE can be used to develop resilience (Perera, Boyd, Wilkins, \& Itty, 2015), three key aspects enhance energy systems resiliency: prevention, recovery and survivability (Electric Power Research Institute, 2009) did not apply in the case of Rukua. The use of the electricity was mainly for activities which did not defer resilience and energy conservation was not prioritised as real costs were subsided by the government by up to 95\% (Republic of Fiji, 2014). In any case, the RE dimensions of resilience suggested in this study can be tested through further research.

Innovation is also related to location (Tim, 2002). This study reveals that, through a design of technological interventions which focus on socio-technological interface, place-based resilience can be increased through improved planning. As (Gupta, et al., 2010) state, "we increase adaptive capacity when we enable social actors to design new institutions and inform existing ones to better respond and adapt to a changing environment". (MeinzenDick \& Knox, 2011) (Fidelman, Van Tuyen, Nong, Nursey-Bray, Keoc, \& Owusu, 2016) argue that it is important to create decentralized and more participatory and collaborative conditions in the management of energy resources. It is this element that permits the innovation to be fully contextualise and flourish.

Thus, for RE, or other innovations, to become a more impactful agent promoting, appropriate intervention planning should be in place. In this study we framed this planning around the MMM interventions (management, 
maintenance and monitoring). At a local level, increase of ownership, supported economic development and improved equitability are the main elements that should prevail. Enhancing the local ownership of the innovation systems is especially important, as for the time being there is the feeling that the solar systems belong to the government and are under the responsibility of the government.

\section{Conclusions}

The case studies are focussed on the process of innovation adoption and performance in indigenous and vulnerable island communities which encapsulate many of the contemporary sustainable development challenges (Bryne, Smith, Watson, \& Ockwell, 2011) (Connell, 2013), (Kelman, Burns, \& Machado des Johnasson, 2015). The work was targeted at research gaps associated with energy innovation in a contemporary development context, in order to demonstrate how institutional and behavioural factors as well as national cultures shape the innovation diffusion which has implications for both investors and decision-makers (Masini \& Menichetti, 2013) (Desmarchelier \& Fang, 2016).

Our work confirms and strengthens previous research findings according which although technology foresight has been increasingly undertaken by developing countries to identify technologies whose adoption might serve as a platform for future economic growth, those foresight activities have not necessarily resulted in well-developed policy initiatives (Bryne, Smith, Watson, \& Ockwell, 2011) (Feigea \& Vonortas, 2016). In the cases presented here, there was significant additional potential for innovative systems to build resilience through improving the socialtechnological surrounding nexus as well as to reduce unintended and negative social consequences of the innovation implementation. The challenge of turning innovative technology into a more holistic development instrument, is addressed in this work through improved MMM (management, maintenance and monitoring) interventions alongside RE systems installation. Analysis of the MMM intervention illustrated the potential for strengthening of the technical-social interface and further accrual of resilience benefits to the community.

Innovation is seen as a key element in transition research and socio-ecological resilience focussing on human wellbeing in the face of uncertainty and change (Olsson et al., 2014). However, this research identifies that in vulnerable and indigenous communities, the process concerning innovation adoption and diffusion needs to be planned beyond just technological deployment, and inculcate a holistic approach across the cultural, social, economic dimensions. Much of the global aspiration involved in transitioning towards the Sustainable Development Goal targets will involve technology-based innovation, but the work presented here provides a salutatory and disquieting backdrop for more indigenous and vulnerable communities which are most at risk to sustainable development challenges.

Access to development finance and the need for technological transfer to proceed to more sustainable and lowcarbon futures reflect the present global rhetoric from Pacific islands and other Small Island Developing States (SIDS). However, even with mobilised resources and ready access to technical innovation, without more holistic planning of the innovation process there is a concern that many resilience outcomes will be weak and sub-optimal. The existential threats to many local communities, and some nations, in the Pacific, may mean that sub-optimal innovation will not be enough.

\section{Acknowledgements}

Authors would like to thank Valerie Angeon, Alison Newell, Peter Nuttall, and Salome Tawake for their contributions to this research. Authors would also like to thank both communities of Naceva and Rukua villages for their valuable insights. Finally, authors are grateful to the two anonymous reviewers of earlier drafts for constructive comments that helped to improve the paper. 
The study has been funded under the project TILOS (Horizon 2020 Low Carbon Energy Local / small-scale storage LCE-08- 2014). This project has received funding from the European Union \& Horizon 2020 research and innovation programme under Grant Agreement No 646529. 


\section{Bibliography}

Agence Francaise et Developpement. (2014). Renewable Energy in the Pacific Islands: an Overview and Exemplary Projects. http://www.afd.fr/webdav/site/afd/shared/PUBLICATIONS/RECHERCHE/Scientifiques/Seriegrise/Energies-renouv-VA.pdf

Akter, S., \& Mallick, B. (2013). The Poverty Vulnerability Resilience Nexus: Evidence from Bangladesh. Ecological Economics, 96:114-124.

Alchian, A., \& Demsetz, H. (1972). Production, Information Costs and Economic Organization. American Economic Review, 62(5):777-795.

Alliance of Small Island States. (2008). Proposal to the AWG-LCA: Multi-Window Mechanism to Address Loss and Damage from Climate Change Impacts. http://unfcc.int/files/kyoto protocol/application/pdf/aosisinsurance061208.pdf

Asian Development Bank . (2014). ADB basic statistics 2014. Consulté le April 19, 2016. http://www.adb.org/publications/basicstatistics-2014.

Atteridge, A., \& Canales, N. (2017). Climate finance in the Pacific: an overview of flows to the region's Small island Developing States. Issue Working Paper 2017-04, Stockholm Environment Institute.

Australian Aid. (2011). Pacific Climate Change Science Program. International Climate Change Adaptation Initiative.

Bainimarama, J. (2013). Speech at the opening of the Rukua Smart Solar Power Project. Rukua, Fiji. http://www.ruraldev.gov.fj/index.php/19-frontpage-articles/75-commissioning-of-tissue-culture-lab-atkoronivia-research-station. Assessed 27 of October 2017.

Barnes, D. (2007). The Challenge of Rural Electrification: Strategis for Developing Countries. Washington DC: RFF Press.

Bayar, Y., \& Alp Ozel, H. (2014). Electricity Consumption and Economic Growth in Emerging Economies. Journal of Knowledge Management, Economics and Information Technology (pp. Vol. IV, Issue 2). Scientific Papers (www.scientificpapers.org).

Berke, P., Chuenpagdee, R., Juntarashote, K., \& Chang, S. (2008). Human-Ecological Dimensions of Disaster Resiliency in Thailand: Social Capital and Aid Delivery. Journal of Environmental Planning and Management, 51(2): 303317.

Brown, B. (2012). Vulnerability is the birthplace of innovation, creativity and change: Brené Brown at TED2012. Consulté le January 19, 2017, on TED blog: http://blog.ted.com/vulnerability-is-the-birthplace-of-innovationcreativity-and-change-brene-brown-at-ted2012/

Brown, K., \& Westaway, E. (2011). Agency, Capacity and Resilience to Environmental Change: Lessons from Human Development, Well-Being and Disasters. Annual Review of Environment and Resources, 36(1):312-342.

Bryne, R., Smith, A., Watson, J., \& Ockwell, D. (2011). Energy Pathways in Low-Carbon Development: From Technology Transfer to Socio-Technical Transformation. STEPS Working Paper.

Burby, R., Steinberg, L., \& Basolo, V. (2003). The Tenure Trap: The Vulnerability of Renters to Joint Natural and Technological Disasters. Urban Affairs Review, 39, p.32.

CARRI, (2017). What is Community Resilience and Why is it Difficult to Measure?. 
Chalvatzis, K., \& Rubel, K. (2015). Electricity Porfolio Innovation for Energy Security: The Case of Carbon Constrained China. Technological Forecasting \& Social Change, 100, 267-276.

Chapin, F., Carpenter, S., Kofinas, G., Folke, C., Abel, N., Clark, W., et al. (2010). Ecosystem stewardship: sustainability strategies for a rapidly changing planet. Trends in Ecology and Evolution, 25, 241-249.

Christopher, M., \& Rutherford, C. (2004). Creating Supply Chain Resilience Through Agile Six Sigma. Critial EYE, Vol.5,pp.24-28.

Collins, R. (2015). Keeping it in the Family? Re-focussing Household Sustainability. Geoforum, 60(2015), pp.22-32.

Connell, J. (2013). Islands at Risk? Environments. Economies and Contemporary Change. Edward Elgar Publishing Limited .

Connor, H. (2008). The Capacity for Sub-National Island Jurisdictions to Increase Autonomy: The Example of Prince Edward Island. (éd. Baldacchino, G. and Stuart, K. (eds) Pulling Strings: Policy Insights for Prince Edward Island from other Sub-National Island Jurisdictions.). Charlottetown, Canada: Island Studies Press.

Craeynest, L. (2010). Loss and Damage from Climate Change: The Cost for Poor People in Developing Countries. ActionAid International Discussion Paper: http://www.actionaid.org/sites/files/actionaid/loss and damage discussion paper by actionaid- nov 2010.pdf

Cutter, S., Barnes, L., Berry, M., Burton, C., Evans, E., Tate, E., et al. (2008). A Place-Based Model for Understanding Community Resilience to Natural Disasters. Global Environmental Change, 18(4):598-606.

Darnhofer, I. (2014). Resilience and Why It Matters for Farm Management. European Review of Agricultural Economics, 41(3):461_484.

Desmarchelier, B., \& Fang, E. (2016). National culture and innovation diffusion. Exploratory insights from agentbased modeling. Technological Forecasting and Social Change, 105, 121-128.

DOE-PI; NREL. (2013). U.S. Energy Sector Vulnerabilities to Climate Change and Extreme Weather. U.S. Department of Energy.

Dornan, M. (2011). Solar-based Rural Electrification Policy Design: The Renewable Energy Service Company (RESCO) Model in Fiji. Renewable Energy 36, 797-803.

Dornan,M. (2014). Access to Electricity in Small Island Developing States of the Pacific: Issues and Challenges. Renewable and Sustainable Energy Reviews, 31(2014)726-735.

Ebbin, S. (2009). Institutional and Ethical Dimensions of Resilience in Fishing Systems: Perspectives from Co-managed Fisheries in the Pacific Northwest. Marine Policy, Volume 33, Issue 2, March 2009, Pages 264-270.

Economic Consulting Associates (2013). Review of the Fiji National Energy Policy.

Eells, G. (2016). Cultivating Resilience. Assessed in June 2016 on TEDx Talk: https://www.youtube.com/watch?v=eLzVJVM1BUc

Electric Power Research Institute. (2009). Enhancing Distribution Resiliency - Opportunities for Applying Innovative Technologies. Technical Research Power.

Elrick-Barr, C., Smith, T., Preston, B., Thomsen, D., \& Baum, S. (2016). How are Coastal Households Responding to Climate Change? Environmental Science \& Policy, Volume 63, September 2016, Pages 177-186. 
Elrick-Barr, C., Thomsen, D., Preston, B., \& Smith, T. (2016b). Perceptions matter: Household Adaptive Capacity and Capability in two Australian Coastal Communities. Regional Environmental Change, pp 1-11.

Engle, N. (2011). Adaptive Capacity and its Assessment. Global Environmental Change, 21, 647-656.

EPSC. (2017). European Political Strategy Centre (EPSC). Strategic Note 7: Integration of Products and Services: https://ec.europa.eu/epsc/file/strategic-note-7-integration-products-and-services_en. Assessed 10 February 2017.

EU, JRC. (2011, October 27). CO2 time series 1990-2011 per region/country. http://edgar.jrc.ec.europa.eu/overview.php?v=CO2ts1990-2011

Feigea, D., \& Vonortas, N. (2016). Context appropriate technologies for development: Choosing for the future. Technological Forecasting and Social Change.

Fidelman, P., Leitch, A., \& Nelson, D. (2013). Unpacking Multilevel Adaptation in the Great Barrier Reef. Global Environmental Change, 23(4), 800-812.

Fidelman, P., Van Tuyen, T., Nong, K., Nursey-Bray, M., Keoc, P., \& Owusu, M. (2016). Adaptive Capacity of Coastal Resource Management Institutions in Cambodia, Viet Nam and Australia. APN Science Bulletin, Issue 6, April 2016.

Fifita, S. (2012). Options for Energy Security in the Small Island States of the Pacific. Presentation at PECC Seminar2 on marine resources: oceans as a source of renewable energy. Hawaii.

Folke, C. (2006). Resilience: The Emergence of a Perspective for Social-Ecological Ssytems Analyses. Global Environmental Change, 16(3) 253-287.

Folke, C., Carpenter, S., Walker, B., Scheffer, M., Chapin, T., \& Rockstrom, J. (2010). Resilience thinking: integrating resilience, adaptability and transformability. Ecology and Society, 15(4).

Gawith, D., Deigneault, A., \& Brown, P. (2016). Does Community Resilience Mitigate Loss and Damage from Climate Related Disasters? Evidence Based on Survey Data. Journal of Environmetal Planning and Management, Volume 59, Issue 12.

Geels, F. (2004). Understanding system innovations: a critical literature review and a conceptual synthesis. System Innovation and the Transition to Sustainability: theory, evidence and policy, 19-47.

Geels, F., \& Kemp, R. (2007). Dynamics in socio-technical systems: Typology of change processes and contrasting case studies. Technology in Society, 29(4), 441-445.

Global Network on Energy for Sustainable Development. (2006). Energy Access - Making Power Sector Reform Work for the Poor. GNESD.

Guha-Sapir, D., Vos, F., Below, R., \& Ponserre, S. (2011). Annual Disaster Statistical Review: The Numbers and Trends. Brussels: CRED.

Gupta, J., Termeer, C., Klostermann, J., Meijerink, S., Van der Brink, M., Jong, P., et al. (2010). The Adaptive Capacity Wheel: A Method to Asess the Inherent Characteristics of Institutions to Enable the Adaptive Capacity of Society. Environmental Science \& Policy, 13, 459-471.

Hills, J., \& Michalena, E. (2013). (Eratum) The "Mega-What" Question: Who is Finally Renewable Energy For? Dans Renewable Energy Governance - Complexities and Challenges- (pp. 249-261). London: Springer. 
Hughes, S., \& Sarzynski, A. (2015). Building Capacity for Climate Change Adaptation in Urban Areas: Editors' Introduction. Urban Climate, 95(2015), pp.1-66.

Ibanez, E. L., Gkriza, K., Mejia-Giraldo, D., Krishnan, V., Mccalley, J., \& Somani, A. (2015). Resilience and Robustness in Long-Term Planning of the National Energy and Transportation System. International Journal of Critical Infrastructures, Volume 12, issue 1-2 .

Interaction Corporation. (2015). Creation of a Sustainable Circulation Society. Interaction Corporation personal files.

IPCC. (2014). Impacts Adaptation and Vulnerability: Summary for Policy Makers". Working Group II, Fifth Assessment Report of the IPCC.

IRENA. (2016). Renewable Capacity Statistics 2016. IRENA.

Jacobs, B., Lee , C., O'Toole, D., \& Vines, K. (2014). Integrated Regional Vulnerability Assessment of Government Services to Climate Change. International Journal of Climate Change Strategies and Management, 6(3), 272295.

Kelman, I., Burns, T., \& Machado des Johnasson, N. (2015). Islander innovation: A research and action agenda on local responses to global issues. Journal of Marine and Island Cultures, 34-41.

Kelman, I., Lewis, J., Gaillard, J., \& Mercer, J. (2011). Participatory action research for dealing with disasters on islands. Island States, 6(1), 59-86.

Keys, N., Bussey, M., Thomsen, D., Lynam, T., \& Smith, T. (2014). Building Adaptive Capacity in South East Queensland. Australian Regional Environmental Change, 14(2014), pp.501-512.

Khodaei, A. (2014). Resiliency-Oriented Microgrid Optimal Scheduling. IEEE Transmission Smart Grid, 5(4) (2014) 1584-1591.

Klein, R., Nicholls, R., \& Thomalla, F. (2003). Resilience to Natural Hazards: How Useful is this Concept? Environmental Hazards, 5:35-45.

Kokologos, D., Tsitoura, I., Kouloumpis, V., \& Tsoutsos, T. (2014). Visual Impact Assessment Method for Wind Parks: A Case Study in Crete. Land Use Policy, Volume 39, pages 110-120.

Kreft , S., Eckstein, D., Dorsch, L., \& Fischer, L. (2016). Global Climate Risk Index 2016: Who Suffers Most From Extreme Weather Events? Weather-related Loss Events in 2014 and 1995 to 2014. Bonn: Germanwatch.

Laskari, M., Karatasou, S., \& Santamouris, M. (2016). The Design of an Energy and Water Advice Programme for LowIncome Households. Energy and Buildings, Volume 110, 1 January 2016, pages 426-434.

Mala, K., Schlapfer, A., \& Pryor, T. (2009). Better or Worse? The Role of Solar Photovoltaic (PV) Systems in Sustainable Development: Case Studies of Remote Atoll Communities in Kiribati. Renewable Energy, 34(2009) 358-361.

Malone, E., \& Engle, N. (2011). Evaluating Regional Vulnerability to Climate Change: Purposes and Methods. Wiley Interdisciplinary Reviews: Climate Change, Vol.2 No.3, pp.462-474.

Manyena, S. (2006). The Concept of Resilience Revisited. Disasters, Volume 30, Issue 4, pages 434-450.

Martinot, E., Cabraal, A., \& Mathur, S. (2000). World Bank Solar Home System Projects: Experiences and Lessons Learned 1993-2000. Washington DC: World Bank. 
Maru, Y., Stafford Smith, M., Sparrow, A., Pinho, P., \& Dube, O. (2014). A Linked Vulnerability and Resilience Framework for Adaptation Pathways in Remote Disadvantaged Communities. Global Environmental Change 28: 337350 .

Masini, A., \& Menichetti, E. (2013). Investment decisions in the renewable energy sector: An analysis of non-financial drivers. Technological Forecasting and Social Change, 80(3), 510-524.

Mathew, L., \& Akter, S. (2015). Loss and Damage Associated with Climate Change Impacts. In J. T. W.-Y. Chen, Handbook of Climate Change Mitigation and Adaptation, 1st ed. New York: Springer.

McLennan, B., \& Handmer, J. (2012). Changing the Rules of the Game: Mechanisms that Shape Reponsibility Sharing from beyond Australian Fire and Emergency Management. Australian Journal of Emergency Management, 27(2012), pp.7-13.

Meinzen-Dick, R., \& Knox, A. (2011). Collective Action, Property Rights and Devolution of Natural Resource Management:A Conceptual Framework. Dans A. \&. R.Meinzen-Dick (Éd.), Collective Action, Property Rgiths and Devolution of Natural Resource Management: Exchange of Knowledge and Implications for Policy (pp. 41-73). Puerto Azul, The Philipines: DSE/ZEL.

Mercer, J., Kelman, I., Taranis, I., \& Suchet-Pearson, S. (2010). Framework for Integrating Indigenous and Scientific Knowledge for Disaster Risk Reduction. Disasters, 34(1), 214-239.

Miara, A., Vorosmarty, C., Wollheim, W., \& Rosenzweig, B. (2013). Riverine Ecosystem Services and the Thermoelectric Sector: Strategic Issues Facing the Northeastern United States. Environmental Research Letters, 8(2):025017.

Michalena, E., \& Frantzeskaki, N. (2013). Moving forward or slowing-down? Exploring what impedes the Hellenic energy transition to a sustainable future. Technological Forecasting and Social Change, Volume 80, Issue 5, pp. 977-991.

Michalena, E., \& Hills, J. (2012). Renewable Energy Issues and Implementation of European Energy Policy: The Missing Generation? Energy Policy, Volume 45, pp.201-216.

Michalena, E., \& Hills, J. (2013). Renewable Energy Governance: Is it Blocking the Technically Feasible? Dans Renewable Energy Governance - Complexities and Challenges- (pp. pp.3-8). London: Springer.

Michalena, E., \& Hills, J. (2016). Paths of Renewable Energy Development in Small Island Developing States of the South Pacific. Manuscript accepted for publication from the journal Renewable \& Sustainable Energy Reviews in April 2016.

Monnereau, I., \& Abraham, S. (2013). Limits to Autonomous Adaptation in Response to Coastal Erosion in Kosrae, Micronesia. International Journal of Global Warming , 5(4):416-432.

Moser, S., \& Pike, C. (2015). Community Engagement on Adaptation: Meeting a Growing Capacity Need. Urban Climate, 14(2015), pp. 111-115.

Nelson, D. (2011). Adaptation and Resilience: Responding to a Changing Climate. Wiley Interdisciplinary Reviews: Climate Change, 2(1):113_120.

New Zealand Government. (2016, June 7). Statement. Pacific Energy Gonference . New Zealand. https://www.mfat.govt.nz/assets/ securedfiles/Aid-Prog-docs/Energy-Conference-2016-OutcomeStatement.pdf 
Niez, A. (2010). Comparative Study on Rural Electrification Policies in Emerging Economies - Keys to Succesful Policies. International Energy Agency.

Nutall, P., Newell, A., Prasad, B., Joeli, V., \& Holland, E. (2014). A Review of Sustainable Sea-transport for Oceania: Providing Context for Renewable Energy Shipping for the Pacific. Marine Policy, 283-287.

OECD . (2005). Growth in Services - Fostering Employment, Productivity and Innovation. Meeting of the OECD Council at Ministerial Level.

OECD. (2010). The Changing Consumer and Market Landscape. Consumer Policy Toolkit.

OECD. (2016). Geographical Distribution of Financial Flows to Developing Countries 2016: Disbursements, Commitments, Country Indicators. http://www.keepeek.com/Digital-Asset-

Managment/oecd/development/geographical-distribution-of-financial-flows-to-developing-countries2016_fin_flows_dev-2016-en-fr. Assessed 17 June, 2016.

Olsson, P., Folke, C., \& Hahn, T. (2004). Social-ecological transformation for ecosystem management: the development of adaptive comanagement of a wetland landscape in southern Sweden. Ecology and Society, 9(4).

Olsson, P., Galaz, V., \& Boonstra, W. (2014). Sustainability transformations: a resilience perspective. Ecology and Society, 19(4).

Ostrom, E. (2015). Governing the Commons - The Evolution for Collective Action (éd. Canto Classics). Cambridge University Press.

Ostrom, E., Gibson, C., Shivakumar, S., \& Andersson, K. (2001). Aid, Incentives and Sustainability: An Institutional Analysis of Development Cooperation. (éd. Sida studies in evaluation). Stockholm: Swedish International Development Cooperation Agency.

Ostrom, E., Schroeder, L., \& Wynne, S. (1993). Institutional Incentives and Sustainable Developoment. Boulder: Westview Press.

Pelling, M. (2011). Adaptation to Climate Change: From Resilience to Transformation. London: Routledge.

Perera, N., Boyd, E., Wilkins, E., \& Itty, R. (2015). Litterature Review on Energy Access and Adaptation to Climate Change. UK Department for International Development (DFID). Adaptation Knowledge and Tools. Evidence on Demand.

Pothitou, M., Hanna, R., \& Chalvatzis, K. (2016). Environmental Knowledge, Pro-environmental Behavior and Energy Savings in Households: An Empirical Study. Applied Energy, 184, 1217-1229.

Pothitou, M., Hanna, R., \& Chalvatzis, K. (2017). ICT Entertainment Appliances' Impact on Domestic Electricity Consumption. Renewable and Sustainable Energy Reviews (in press).

Prasad, S., Schulte, V., \& Bijay, P. (2013). An Overview of Energy Policy and Security in the Pacific Region. Dans Global Energy Policy and Security (pp. Volume 16 of the series Lecture Notes in Energy pp 277-292). Springer.

Republic of Fiji. (1993). Rural Electrification Policy.

Republic of Fiji. (2007). 2007 Census of Population. Suva: Statistics FIBo.

Republic of Fiji. (2012). National Climate Change Policy. Suva: Secretariat of the Pacific Community. 
Republic of Fiji. (2012). Poverty in Fiji. Bureau of Statistics.

Republic of Fiji. (2013). Draft National Energy Policy.

Republic of Fiji. (2014). A Green Growth Framework for Fiji - Restoring the Balance in Development that is Sustainable for Our Future.

Republic of Fiji. (2015). Fiji's Intended Nationally Determined Contribution. Dans National Climate Change Policy (p. 33). Secretariat of the Pacific Community (SPC).

Republic of Fiji. (2016). Rapid Assessment and Gap Analysis. Sustainable Energy for All (SE4All).

Santamouris, M., \& Kolokotsa, D. (2015). On the Impact of Urban Overheating and Extreme Climatic Conditions on Housing, Energy, Comfort and Environmental Quality of Vulnerable Population in Europe. Energy and Buildings, Volume 98, 1 July 2015, pages 125-133.

Singh, A. (2012). Renewable Energy in the Pacific Island Countries: Resources, Policies and Issues. Management of Environmental Quality, 23(3):254-263.

Smith, A., Fressoli, M., \& Thomas, H. (2014). Grassroots Innovation Movements: Challenges and Contributions. Journal of Cleaner Production, 63, 114-124.

Stone, J. (2013). Climate Change: Adaptation, Resilience and Energy Security . Expert response by Jeremy Stone. Boiling Point-Climate Change: Adaptation, Resilience and Energy Security.

The Economist, Intelligence Unit. (2016, October 27). Country profiles (Fiji). http://country.eiu.com/fiji

Tierney, K., \& Bruneau, M. (2007). Conceptualizing and Measuring Resilience: A Key to Disaster Loss Reduction. Transportation Research News.

Tim, T. (2002). Innovation, Technology Policy and Regional Development: Evidence from China and Australia. Edward Elar Publishing.

Tompkins, E.L., \& Adger, W. (2004). Does Adaptive Management of Natural Resources Enhance Resilience to Climate Change? Ecology and Society, 9(2):10.

UkAid. (2011, June 15). Defining Disaster Resilience: A DFID Approach Paper. https://www.gov.uk/government/uploads/ssytem/uploads/attachement_data/file/186874/definingdisaster-resilience-approach-paper.pdf. Assessed 5 of December 2017

UNEP. (2014). Emerging Issues for Small Island Developing States / Results of the UNEP Foresight Process. Nairobi, Kenya: United Nations Environment Program (UNEP).

UNEP; UNDESA; FAO. (2012). SIDS-FOCUSED GreenEconomy: An Analysis of Challenges and Opportunities.

UNISDR. (2005). World Conference on Disaster Reduction. Japan:

http://www.unisdr.org/2005/wcdr/intergover/official-doc/L-docs/Hyogo-framework-for-action-english.pdf.

United Nations . (2011). http://www.preventionweb.net/enghlish/hyogo/gar/2015/en/home/data.php?iso=FJI.

United Nations. (2011). World Risk Index. http://ehs.unu.edu. Assessed 15 of June 2016. 
United Nations. (2015). Global Assessment Report on Disaster Risk Reduction 2015.

http://www.preventionweb.net/english/hyogo/gar/2015/en/home/GAR_pocket/Pocket\%20GAR_11.html. Assesed on 15 of June 2016.

Wade, H. (2003). Survey of RESCO projects. OPRET, Fiji Department of Electricity.

Walters, H. (2012). Vulnerability is the birthplace of innovation, creativity and change: Brené Brown at TED2012. TED blog: http://blog.ted.com/vulnerability-is-the-birthplace-of-innovation-creativity-and-change-brene-brownat-ted2012/. Assessed $19 \mathrm{f} \mathrm{January} 2016$.

Wamsler, C., \& Brink, E. (2014). Interfacing Citizens' and Institutions' Practice and Responsibilities for Climate Change Adaptation. Urban Climate , 7 (2014), pp.64-91.

Warner, K., \& Van der Geest, K. (2013). Loss and Damage from Climate Change: Local-Level Evidence from Nine Vulnerable Countries. International Journal of Global Warming , 5(4):367-386.

Warner, K.; Van der Geest, K.; Kreft, S. (2013). Pushed to the Limit: Evidence of Climate Change-Related Loss and Damage when People face Constraints and Limits to Adaptation. http://preventionweb.net/go/35509

Wise, R., Fazey, I., Stafford Smith, M., Park, S., Eakin, H., Archer Van Garderen, E., et al. (2014). Reconceptualizing Adaptation to Climate Change as Part of Pathways of Change and Response. Global Environmental Change: Human and Policy Dimensions, 28:325-336.

Wolf, F., Surroop, D., Singh, A., \& Leal, W. (2016). Energy Access and Security Strategies in Small Developing States. Energy policy, DOI:10.1016/j.enpol.2016.04.020.

Woodruff, A. (2007). The Potential for Renewable Energy to Promote Sustainable Development in Pacific Island Countries. Suva: SOPAC.

World Bank. (2000). Energy Services for the World' Poor. Washington DC: The World Bank.

World Bank. (2015). Overview. http://www.worldbank.org/en/country/pacificislands/overview. Assessed on 5 of October, 2015.

World Bank. (2016). Technical and Economic Assessment of Grid, Mini-grid and Off-grid Electrification. Washington DC: The World Bank.

Zafirakis, D., \& Chalvatzis, K. (2014). Wind Energy and Natural Gal-based Energy Storage to Promote Energy Security and Lower Emissions in Island Regions. Fuel, 203-219.

Zafirakis, D., Chalvatzis, K., \& Baiocchi, G. (2015). Embodied CO2 Emissions and Cross-border Electricity Trade in Europe: Rebalancing Burden Sharing with Energy Storage. Applied Energy, 144, 283-300.

Zafirakis, D., Chalvatzis, K., Baiocchi, G., \& Daskalakis, G. (2016). The Value of Arbitrage for Energy Storage: Evidence from European Electricity Markets. Applied Energy, 184, 971-986.

Zafirakis, D., Elmasides, C., Sauer, D., Leuthold, M., Merei, G., Kaldellis, J., et al. (2014). The Multiple Role of Energy Storage in the Industrial Sector: Evidence from Greek Industrial Facility. Energy Procedia178-185, 46. 